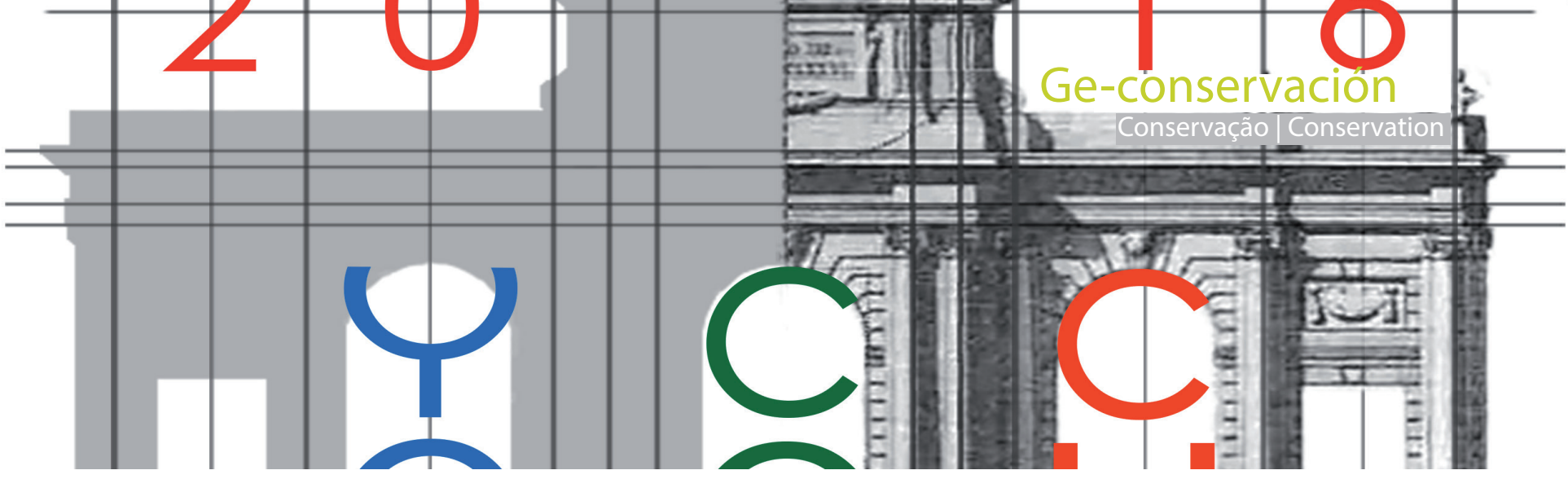

\title{
Stone provenance and conservation of the Trinitarias Descalzas of San Ildefonso convent, Madrid (Spain)
}

\author{
David Martín Freire-Lista, Rafael Fort
}

\begin{abstract}
The characterization of building stones used in monuments and the location of their historic quarries is key for maintenance and restoration works. The four most representative building stones of Madrid: flint, granite, Cretaceous dolostone and Miocene limestone, have been used in the Trinitarias Descalzas of San Ildefonso convent of this city. A plaque of Carrara marble was placed on the convent façade in honour of the Spanish writer Miguel de Cervantes in 1870.

The decay of the stones was determined by characterization techniques such as optical polarization and fluorescence microscopy and spectrophotometry. This technique gave information about the colour change between the plinth granite of the convent and quarry granite where it was extracted. The historical documentation complements these data.
\end{abstract}

Key words: provenance, preventive conservation, building stone, microcracks

\section{Procedencia y conservación de la piedra del convento de las Trinitarias Descalzas de San Ildefonso de Madrid (España)}

Resumen: La caracterización de piedras utilizadas en monumentos y la ubicación de sus canteras históricas es clave para los trabajos de mantenimiento y restauración. En el convento de las Trinitarias Descalzas de San Ildefonso de Madrid se han utilizado las cuatro piedras de construcción más representativas de esta ciudad: sílex, granito, dolomía cretácica y caliza miocena. En 1870 se colocó una lápida tallada en mármol de Carrara en la fachada principal en honor al escritor Miguel de Cervantes.

El deterioro de las piedras se determina con técnicas de caracterización como microscopía óptica de polarización y de fluorescencia, así como la espectrofotometría que da información sobre el cambio de color que han experimentado las piedras con relación a las extraídas en cantera. La documentación histórica complementa estos datos.

Palabras clave: procedencia, conservación preventiva, piedra de construcción, microfisuras

\section{Introduction}

Much of the built heritage that exists today was made in times when current decay agents that can reach and degrade it were not known. Today these buildings are vulnerable to these agents, natural or man-made, which act continuously or in short periods of time. The risks affecting building heritage should be evaluated using different techniques (Del Egido 2013: 7) to define prevention strategies as the heritage stones are irreplaceable and are part of the human history and therefore its preservation is of utmost importance (García 1999; Rodríguez 2009: 246). As various disciplines are involved in conservation, decisions on preservation or restoration of the built heritage must be consensual. It is essential to carry out a preliminary investigation before undertaking any intervention (Gómez and Gómez 2001: 640; Gómez 2008). European directives and the scientific community advocate preventive conservation against the interventional conservation done in the past, which means that causes of decay should be identified and measures taken to mitigate against them (Bruquetas 2014: 12). Conservation and restoration are complementary actions and a restoration program must always include appropriate methods of safeguarding, maintenance and prevention of damage (Cirujano and Laborde 2001: 696). 
The convent of Trinitarias Descalzas of San Ildefonso (CTDOSI) in Madrid (Spain) was installed in houses of the Cantarranas street in 1612, today known as Lope de Vega street (Tovar Martin1974). The first work was the construction of a small provisional church where the Spanish writer Miguel de Cervantes Saavedra was laid to rest in 1616.

The demolition of the church and some houses began in 1673. A new church was built on Cantarranas street. The first mass in the church was held in 1697. The façade of the church is composed of three levels. There are three arcades occupying the entire width of the façade in the first level. These arches are carved in granite. On the second level a central bas-relief and three coats of arms are prominent. Two are located on the sides of the bas-relief and the other is above it. Above both lateral shields there is a crown and a porthole and above the central shield there is a crown and a central window with jambs and lintels of granite. The third level features a triangular pediment brick bordered by granite ashlar and in whose centre a porthole opens also with a granite edge which finishes off the church. The pediment is crowned by a central cross and lateral decorative vases of granite. Corner stones of granite are on both sides of the main façade of the church.

Once the church was completed, the new convent was built. Neighbouring houses were bought and reformed to form the present convent between the streets of Huertas and Lope de Vega until the eighteenth century. The plinth is the structural element where more building stones have been used [Figure 1] , since the building's walls are built with bricks. The convent was declared a national monument in 1921. The Royal Spanish Academy restored the church in
1869 and 1939 to prevent its possible demolition. Today the convent is listed as a building of cultural interest.

The objectives of this paper are to determine the stones used in the construction of the convent and their origin quarries and the decay that occurs in the granite plinth to ensure that in future interventions restoration work uses original stones or stones with similar characteristics.

The geological history, petrographic and petrophysical properties of building stones in addition to climate, pollution and conditions of use, in conjunction with other factors influence the durability of building stones (Fort et al. 2011: 142; Sousa 2014: 584). When the stones are subjected to temperature changes (Gómez-Heras, 2006, 2008, 2009; Liu et al. 2015; Vazquez et al. 2016), humidity (Freire-Lista and Fort 2016: 239) and urban environment are more susceptible to decay (Pérez-Monserrat et al. 2013: 1076; Sajid et al. 2016: 53).

\section{Methods \& methodology}

An intensive search of historical documentation was done. Historical documents have provided data about stone provenance and historical photographs have provided information about materials used during interventions in the last centuries.

A small granite sample was taken from the plinth. A thin section from this sample was impregnated with fluorescein. Sawing was performed at a low speed (120 rpm) and a low strain so as not to generate microcracks.
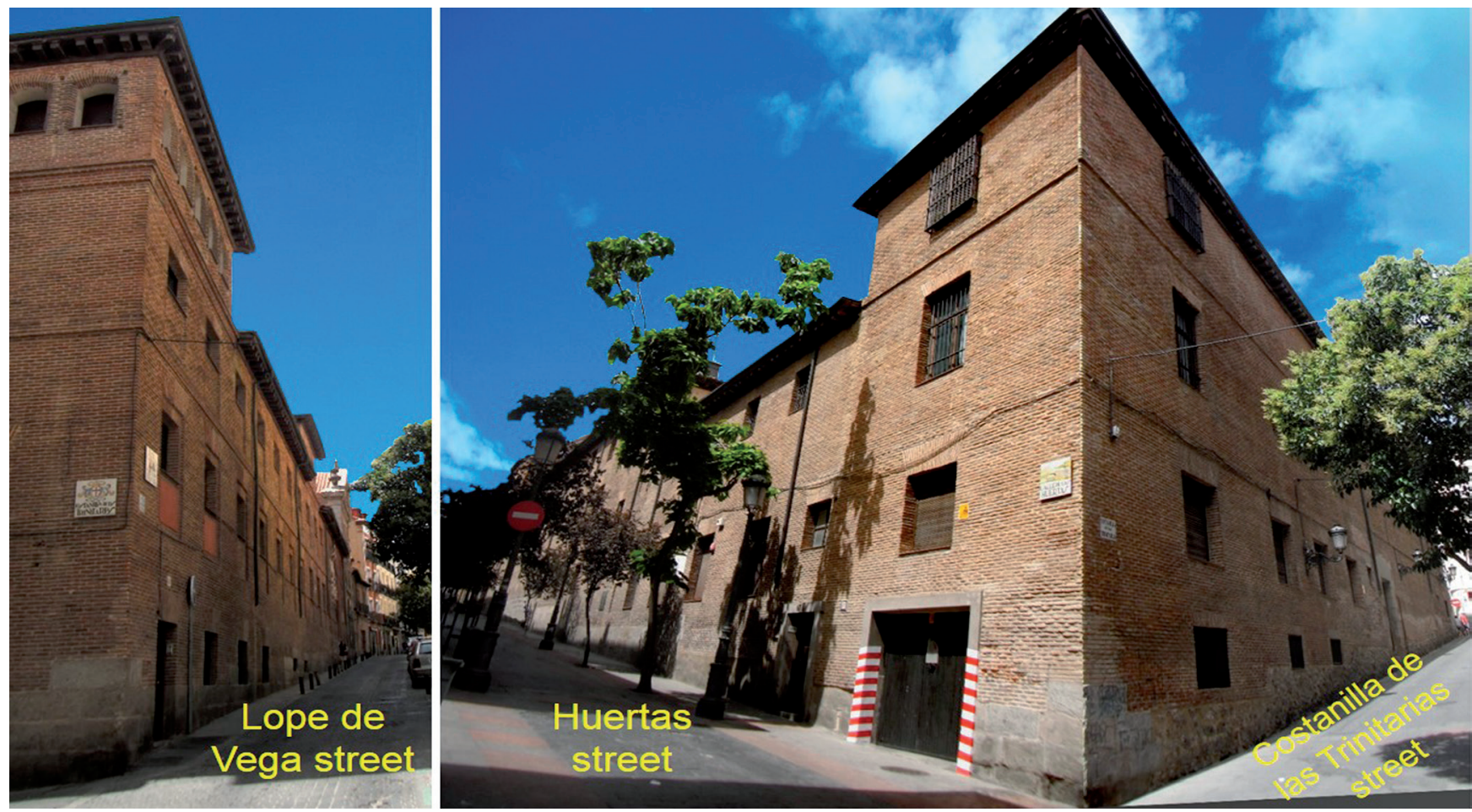

Figure 1.- The three façades of the Convent of Trinitarias Descalzas of San Ildefonso (Madrid). 


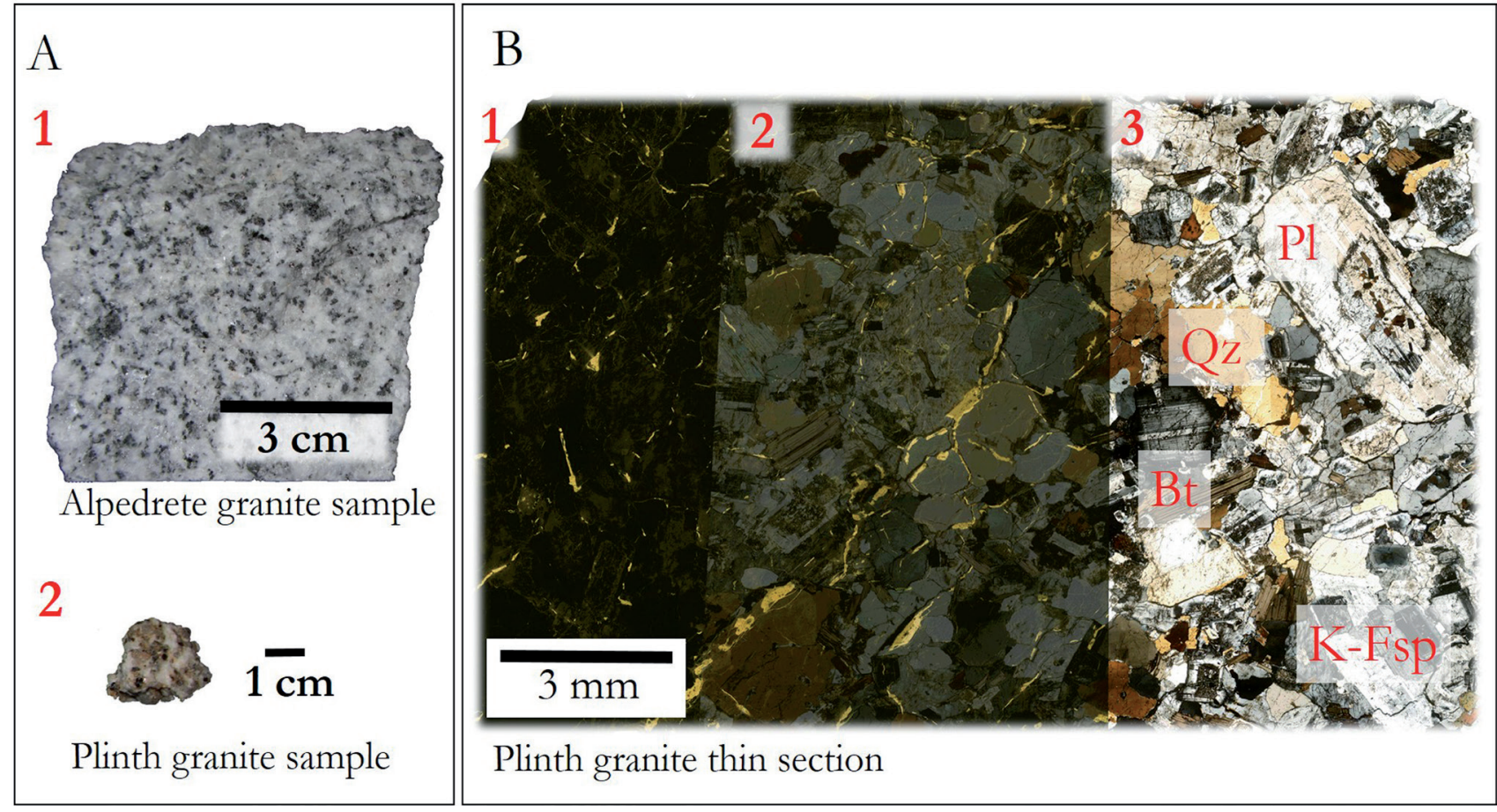

Figure 2.- A: Granite samples. A1. Fresh granite sample from an Alpedrete quarry. A2. Plinth granite sample. B thin section removed along a granite ashlar sample from CTDOSI plinth. B1: Fluorescence light micrograph mosaic, showing microcracks. B2: Fluorescence micrograph mosaic overlaid on polarized micrograph mosaic showing microcracks and mineralogy; B3: crossed nicols mosaic; Biotite (Bt), quartz (Qz), plagioclase (PI), Potassium feldspar (K-Fsp).

Granite was characterized under an Olympus BX 51 polarized light microscope fitted with a DP 12-coupled (6 V/2.5 ^) with an Olympus digital camera and Olympus DP-Soft software (version 3.2). Microcracks were characterized with the same equipment configuration by adding a mercury lamp and fluorescence microscopy Olympus U-RF-T. Photomicrographs were performed with both polarized light and mercury lamp light. With the photomicrographs of each microscopic technique a mosaic made up of 120 photomicrographs with an area of approximately $\pm 4 \mathrm{~cm}^{2}$ was built. Polarization microscopy has been used to study mineralogy and texture and fluorescence microscopy to study microcracks [Figure 2]. Six equidistant lines ( $1.5 \mathrm{~cm}$ each) were drawn on the fluorescence micromosaic and microcracks intersecting the six lines were counted (Freire-Lista et al., 2015a). The result of the count number was divided by 90 to obtain the linear microcracks density (microcracks per millimeter) (Sousa et al., 2005: 158). A sample from an Alpedrete quarry, located at coordinates 40.662563, -4.013308, was taken to compare the colour between the granite from the quarry and the CTDOSI plinth [Figure 2A]. Once the plinth granite sample had reached a constant mass, 10 colour measurements were taken. These measurements were averaged. Granite colour was measured with a Minolta CM-700d / 600D with a CM-S100 W COLOR DATA Software SpectraMagic NX spectrophotometer.

The CIELAB system (CIELAB, 1976) colour parameters were used: luminosity $\left(L^{*}\right)$, red to green coordinate $\left(a^{*}\right)$ and blue to yellow coordinate $\left(b^{*}\right)$. The Spanish and European standard UNE-EN 15886, 2011 yellow $\left(\mathrm{Yl}^{*}\right)$ and white $\left(\mathrm{W} \mathrm{I}^{*}\right)$ indices were obtained. The overall colour change, $\Delta \mathrm{E}^{*}=$ $\sqrt{ }\left(\Delta \mathrm{L}^{*}\right)^{2}+\left(\Delta \mathrm{a}^{*}\right)^{2}+\left(\Delta \mathrm{b}^{*}\right)^{2}$ was determined.

Historical books and documents of the convent were used to determine the provenance of flint used in the plinth, the stones used in the coat of arms, crowns, bass-relief and memorial plaque.

\section{Results \& discussion}

\section{-Characterization and origin of CTDOSI stones}

The stones used in the CTDOSI are those that are traditionally used in Madrid (Fort et al. 2013: 421). These include flint, Alpedrete granite, Cretaceous dolostone and Miocene limestone of the Madrid basin. Some of these stones have been reused from the houses that were previously on this site. Thus, the convent has plinth masonry sections with flint and granite ashlars. Plinth of the Huertas street is composed by granite ashlars. The plinth of Costanilla de las Trinitarias street is composed of masonry flint. There are granite ashlars and rough flint stones in the plinth of Lope de Vega street [Figure $1]$.

All CTDOSI façades were coated with lime plaster in 1889, and the plinth was plastered in 1899. This plaster was removed after the Spanish Civil War, leaving the brick and stone faces exposed as currently preserved [Figure 3]. 

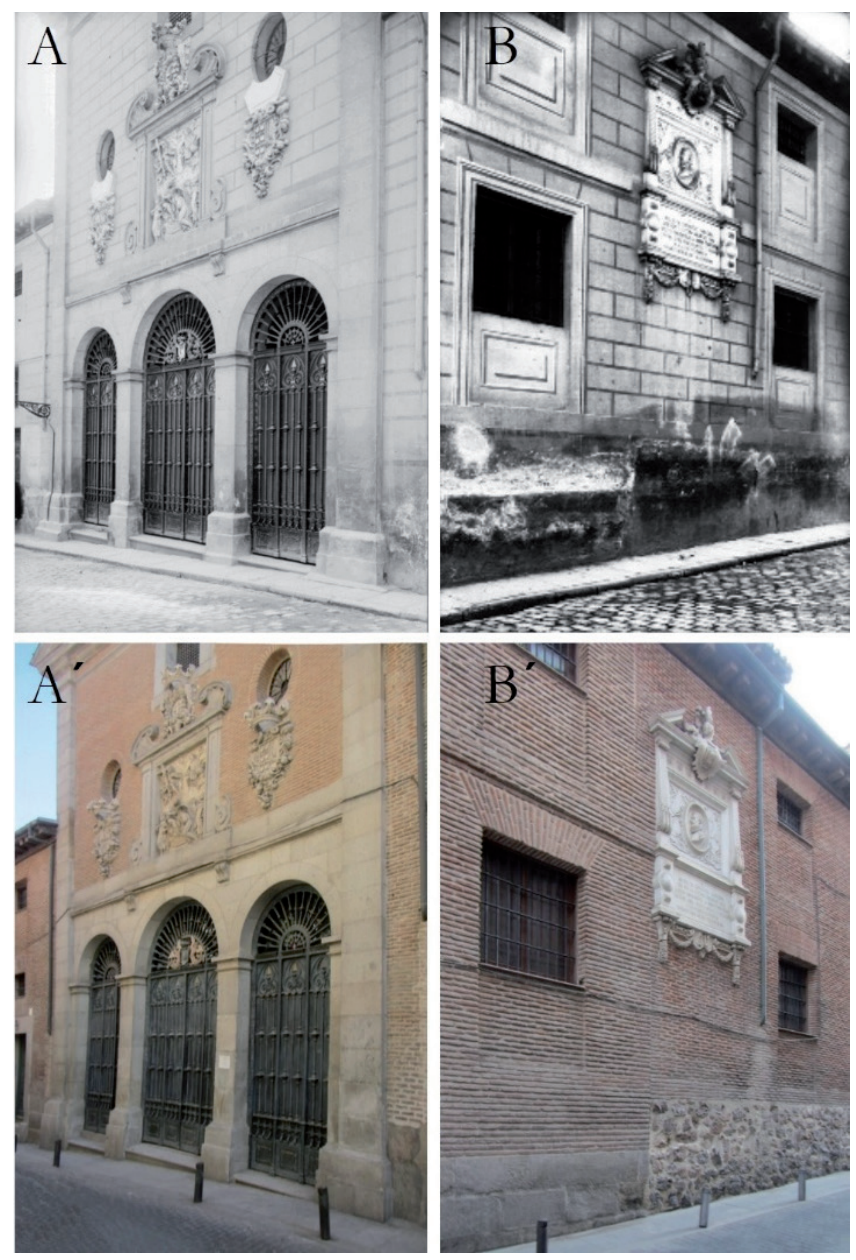

Figure 3.- Top: Photography by the 1930s (Before the Spanish Civil War of 1936-39). Bottom: Current photographs (2016).

The original granite ashlars have very similar characteristics and therefore correspond to the same extraction area. Granite is a hypidiomorphic monzogranite, equigranular of fine to medium crystal size, petrography identical to Alpedrete granite, which has been nominated as a 'Global Heritage Stone Resource' due to its significance in the built heritage of Madrid. (Cooper et al. 2013, Freire-Lista et al. 2015 c, d). The analyzed thin section has mainly intercrystalline and transcrystalline microcracks (Figure 3B). The granite linear microcracks density is 0.7 .

Chromatic parameters of the CTDOSI plinth are represented in Table 1. The $\Delta \mathrm{E}^{*}$ between CTDOSI plinth granite and Alpedrete granite extracted in an active quarry is 11. Plinth granite yellow tones are due to the ashlars extracted from a shallow quarry and therefore they are more altered [Figure 3A] in addition to the decay in situ. Therefore the granite building is more altered than the quarry and it has more yellow tones and less luminosity. Figure $4 \mathrm{~A}$ shows a granite ashlar of the convent plinth with bush-hammered marks, the traditional finishing of granite ashlars in Madrid.

Flint used in the plinth [Figure 3B' and 4B] comes from quarries around Madrid, probably from Vicálvaro, at Cerro de la Mesa quarries (latitude and longitude coordinates: 40.416783, -3.590903). The rock that contains flint is a micritic limestone. Different types of flint, in colour and quality, have been identified. Silicification initially gave rise to opal, which diagenetic weathering subsequently transformed into quartz (Bustillo et al. 2012: 239).

The ornamental part of the building (coat of arms and bassrelief of the church) are carved from creataceus dolostone [Figure 4C and D] (Tovar Martín 1974, 1990). This stone is formed by rhombic dolomite crystals. It is occasionally banded because remnants of its original depositional texture (stromatolitic structures) are preserved. The crystals are microcrystalline, equigranular $(<50 \mu \mathrm{m})$ and dark, with few mottled cores. Porosity is high and poikilotopic and blocky mosaic cements predominate. The presence of localized iron oxyhydroxide deposits gives this stone its reddish colour (Fort et al. 2013: 423).

The stone used for the crowns [Figure $4 C$ and D] is an Upper Miocene limestone from the Madrid sedimentary basin. It is classified as a lacustrine biomicrite/biosparite formed by a bioclast skeleton ( $40 \%$ characeae, ostracods and gastropods) and a paste where the micritic matrix (20-30\%) alternates with sparitic cement (30-40\%). The micrite is a cryptocrystalline mass, calcitic in composition and dark-coloured (Fort et al. 2013: 423).

The commemorative plaque of Cervantes is carved in Carrara marble from the western central area of the Apuan Alps, Tuscany region-Italy. It is a marble lithotype of homogeneous composition of highly uniform white colour, variety commercially identified as Michelangelo marble statuary. This plaque was installed in the convent in 1870 [Figure 4E].

\section{- Stone decay of the CTDOSI}

Pollution agents change over the centuries (Cassar 2016). The convent was built in a rural environment on the outskirts of Madrid and now it is in the city center with pollution and subject to an important tourism flow.

Alpedrete granite has suitable properties to combat humidity and capillary rise. However intrinsic, anthropic or weathering microcracks (Sousa et al. 2016; Kronlund et

Table 1.- Chromatic parameters of CTDOSI plinth granite and quarry granite.

\begin{tabular}{c|c|c|c|c|c}
\hline \multirow{2}{*}{ Granite plinth } & L*(D65) & $\mathbf{a}$ *(D65) & $\mathbf{b} *(\mathbf{D 6 5})$ & $\mathbf{W I ( E 3 1 3 - 7 3 )}$ & YI(E313-73) \\
\cline { 2 - 6 } & 62.6 & 1.0 & 9.9 & 6.0 & 20.6 \\
\hline Granite quarry & 69.3 & -0.6 & 1.0 & 34.9 & 1.8 \\
\hline
\end{tabular}


A

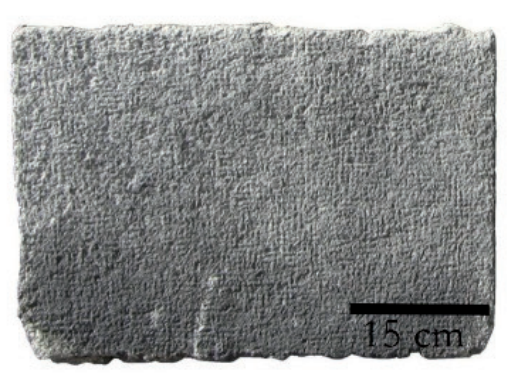

B

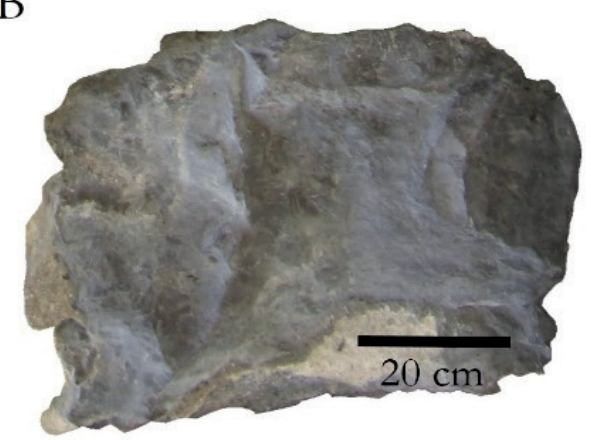

C
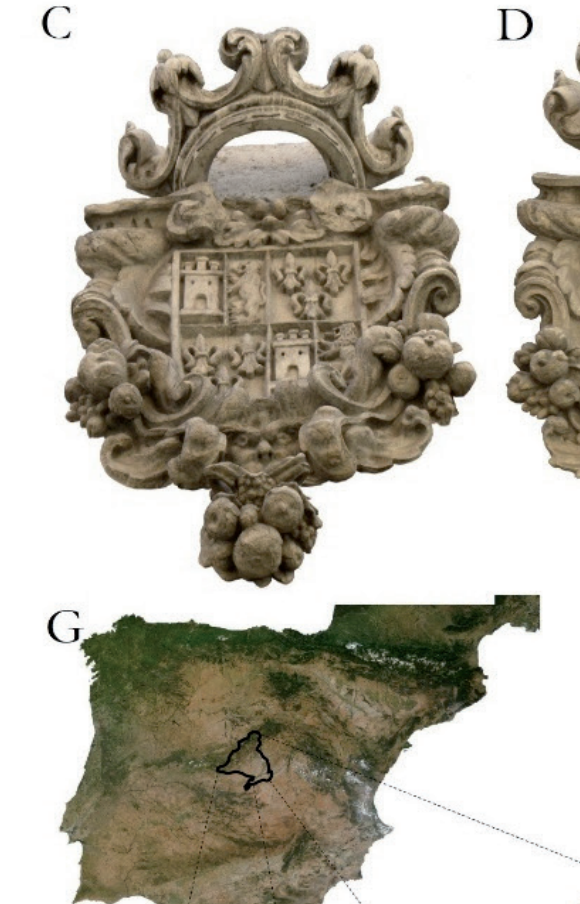

D
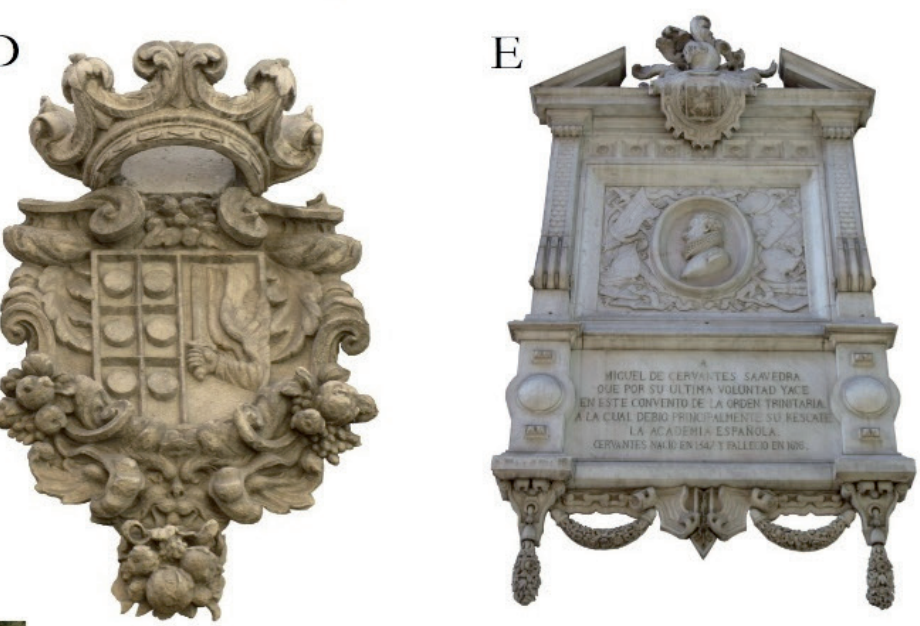

F

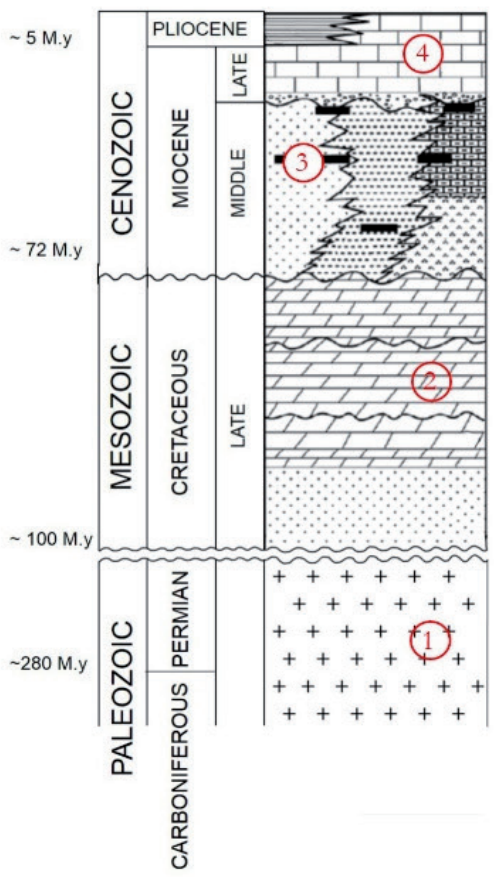

Menduiña and Fort, 2005

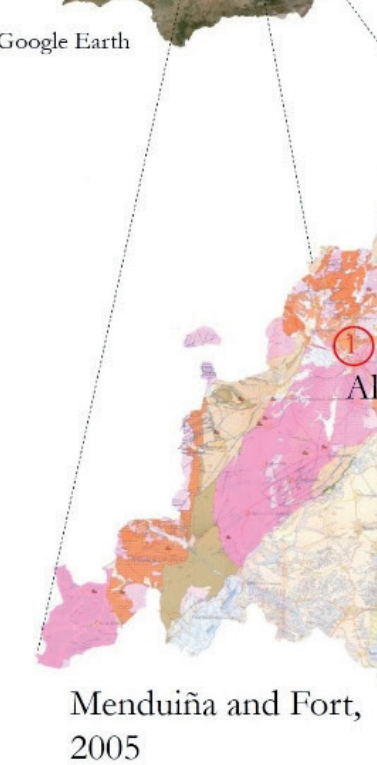

(3)

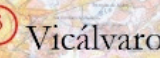

(4)

Colmenar de

Oreja 
al. 2016) like those induced by bush-hammering, produces coalescence of microcracks and creation of a microcracked area between 1-3 mm from the surface which may generate scaling (Freire-Lista and Fort 2016: 937, 2017: 90). Generally the outer surface of granite ashlars follows the exfoliation microcracks direction, so that microcracks are perpendicular to the ground. The water capillary rise along the exfoliation microcracks is a factor contributing to significant decay. Comparing current and historical photographs has revealed that the most deteriorated granite ashlars are located where there are downpipes. Saline efflorescences (Lopez-Arce et al. 2010), microcracks (Siegesmund et al. 1991, 1993), soiling, rounding and granular disaggregation (due to the loss of quartz crystals, potassium feldspars and plagioclase alteration) (FreireLista et al. 2015b), fragmentation (Vasconcelos et al. 2008), biological colonization by micro-organisms (Sanjurjo et al. 2011), black crust (Casal Porto et al. 1991; Silva et al. 2009) and anthropic decay (Rivas et al. 2012; Pozo-Antonio et al. 2016) are the most important forms of decay in the CTDOSI plinth.

The traditional finishing of masonry flint is coarse with conchoidal fractures. These fractures generate planes which have a very smooth surface without internal microcracks due to microcrystalline grain size of the flint. The rough stone flints have a better performance against decay agents.

The dolostone coat of arms shows loss of cohesion and soiling. The limestone of the lateral crowns is, along with the flint, the best preserved stone because lateral limestone crowns have been installed in the CTDOSI more recently [Figure $3 A$ and $A^{\prime}$ ].

The Carrara marble is generally in good condition, its black patina has been eliminated in the subsequent restoration after the Spanish Civil War [Figure 3B and 3B']. Its surface has slight dissolution and increased surface area, which increases vulnerability to decay.

The Huertas street façade has been modified. Doorways have been built by replacing original granite with lower quality artificial materials like ceramic tile. The use of Portland cement between ashlar joints and covering them may also be observed, as well as granite cladding plaques with differing dimensions to the original ashlars have been placed in the lowermost part of the plinth and graffities were painted [Figure 5]. Architecture, restauration and the urban planning must be focused on sustainable conservation (Compitello 1999, Larson 2003).

\section{Conclusions}

CTDOSI preserves most of the original building stones. Knowledge of stones, historic quarries and causes of stone decay are necessary for conservation interventions, especially for reintegration of damaged ashlars and
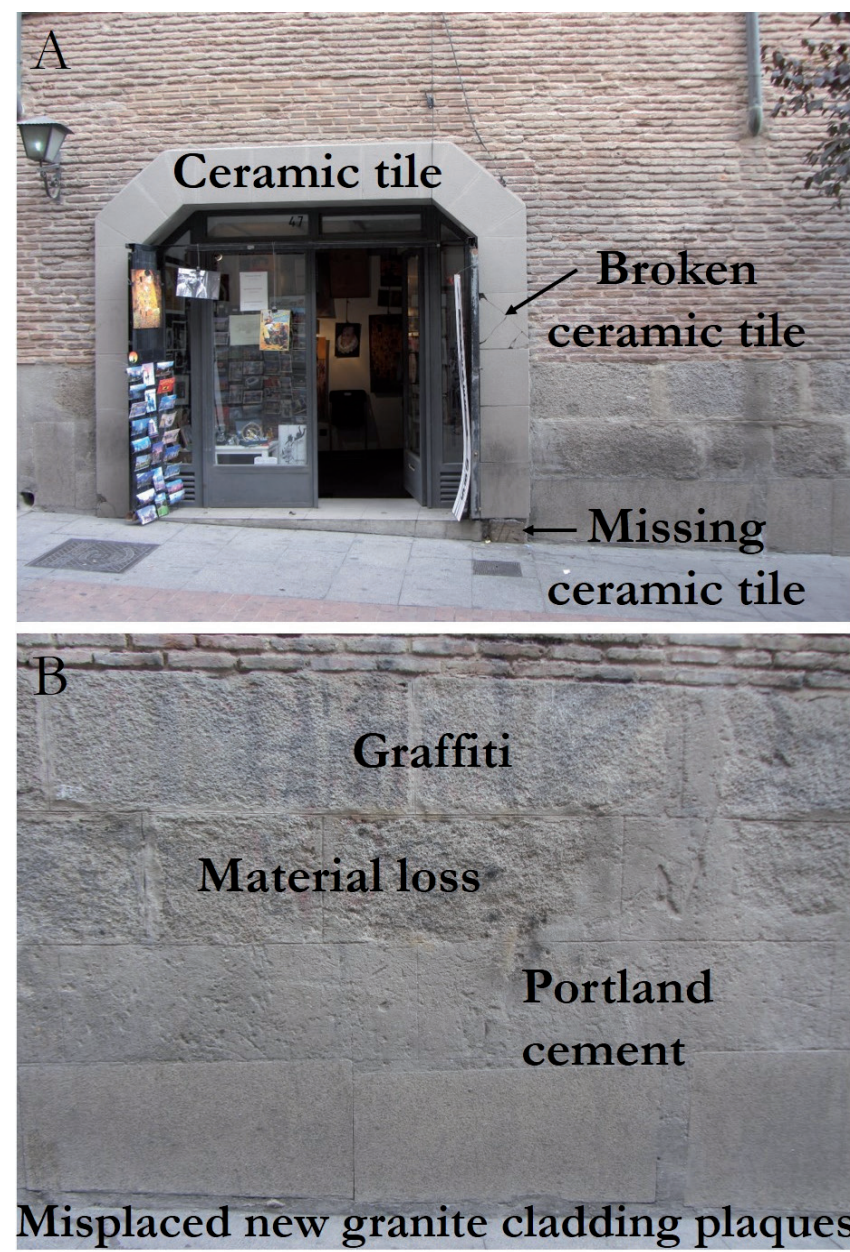

Figure 5.- CTDOSI plinth facing Huertas Street. A: Granite replacement by ceramic tile. B: Anthropic decay in the plinth.

replacing the original stone with compatible materials. Each type of stone that forms the CTDOSI has a different response to decay agents to which they are exposed. CTDOSI features flint masonry plinth on the façades, which face towards Lope de Vega and Cuesta de las Trinitarias streets. Granite is in ashlars of the plinth, arcades of the church façade, corner stones and other elements such as jambs and lintels. The coats of arms are carved in dolomitic stone and the crows are in Miocen limestone of the Madrid basin. The Cervantes commemorative plaque is carved in Carrara marble. The stones show loss of cohesion, soiling, scaling, saline efflorescences, anthropic decay and microcracks (detected by fluorescence microscopy techniques). The granite is beginning to yellow. The flint stones are the best preserved.

Madrid flint originates from ancient quarries near Madrid while the dolomitic stone corresponds to the Cretaceous formations of Madrid. Granite is from Alpedrete pluton and limestone probably from Colmenar de Oreja quarries both in Community of Madrid.

The type of maintenance or cleaning to be applied to these centuries-old stones will be influenced by the decay type, finish and mineralogy, taking special care in the most damaged granite ashlars. 
Granite ashlars of the plinth present a colour difference of 11 with respect to that currently being mined at the quarry. For this reason, when replacing ashlars they should be used from more superficial quarry stones. The surface finishing of the replaced ashlars should be the same or similar to those already in situ.

ACKNOWLEDGEMENTS: This study was funded by the Community of Madrid under the GEOMATERIALS-2CM research Program (S2013/MIT-2914).

Manuscript edited by Mark Wass, www.englishmarkonline. com professional translator and English language science editor.

\section{Bibliography}

BUSTILlO, M.A., PEREZ-JIMENEZ, J.L., BUSTILlO, M. (2012), "Geochemical characterization of sedimentary rocks formed by silicification as supply source of lithic tools (Miocene, Madrid basin)", Revista Mexicana de Ciencias Geológicas, 29: 233-247.

BRUQUETAS GALÁN, R. (2014). "Ge-conservación (España)" Especial section: Quinto Aniversario de Intervención. 10: 11 15.

CASAL PORTO, M., SILVA HERMO, B., DELGADO RODRIGUES, J. (1991). "Agents and forms of weathering in granitic rocks used in monuments". Science, Technology and European Cultural Heritage, 439-442.

CASSAR, J. (2016). "The Historic and Archaeological Heritage: Pollution and Non-Urban Sites" In Urban Pollution and Changes to Materials and Building Surfaces, 255-290, P. Brimblecombe (ed). Imperial College Press.

CIRUJANO GUTIÉRREZ, C., LABORDE MARQUEZE, A. (2001). "La conservación arqueológica", Arbor, 169: 691-709.

COMPITELLO, M.A. (1999). “From Planning to Design: The Culture of Flexible Accumulation in Post-Cambio Madrid", Arizona Journal of Hispanic Cultural Studies, 3: 199-220.

COOPER, B.J., MARKER, B.R., PEREIRA, D., SCHOUENBORG, B. (2013). "Establishment of the "Heritage Stone Task Group" (HSTG)", Episodes, 36: (1) 8-9.

DEL EGIDO, M., JUANES, D., BUESO, M. (2013). “Consideraciones en torno a los estudios científicos aplicados a la conservación del patrimonio cultural", Ciencia y Arte IV, Madrid.

FORT, R., VARAS, M.J., ALVAREZ DE BUERGO, M., MARTIN-FREIRE, D. (2011). "Determination of anisotropy to enhance the durability of natural stone", Journal of Geophysics and Engineering, 8: 132144. doi:10.1088/1742-2132/8/3/S13.

FORT, R., ALVAREZ DE BUERGO, M., PEREZ-MONSERRAT, E.M., GOMEZ-HERAS, M., VARAS-MURIEL, M.J., FREIRE-LISTA, D.M.
(2013). "Evolution in the use of natural building stone in Madrid, Spain", Quarterly Journal of Engineering Geology and Hydrogeology, 46: 421-429.

FREIRE-LISTA, D.M, FORT, R., VARAS-MURIEL, M.J. (2015a). "Freeze-thaw fracturing in building granites", Cold Regions Science and Technology, 113: 40-51. Doi: 10.1016/j. coldregions.2015.01.008.

FREIRE-LISTA，D.M，GOMEZ-VILLALBA， L.S., FORT R. (2015b). "Microcracking of granite feldspar during thermal artificial processes", Periodico di mineralogia, 84 (3A): 519-537.

FREIRE-LISTA, D.M, FORT, R. (2015c). "The Piedra Berroqueña region: candidacy for Global Heritage Stone Province status", Geoscience Canada, 43: 43-52.

FREIRE-LISTA, D.M, FORT, R., VARAS-MURIEL, M.J. (2015d). "Alpedrete granite (Spain). A nomination for the "Global Heritage Stone Resource" designation", Episodes, 38, (2): 1-8.

FREIRE-LISTA, D.M., FORT, R. (2016). "Causes of scaling on brush hammered heritage ashlars. A case study: Plaza Mayor of Madrid (Spain)", Environmental Earth Sciences, 75: 932.

FREIRE-LISTA, D.M., FORT, R. (2017). "Exfoliation microcracks in building granite. Implications for anisotropy", Engineering Geology, 220: 85-93.

GARCÍA FERNÁNDEZ, I.M. (1999). “La conservación preventiva y la exposición de objetos y otras de arte" (serie historia y patrimonio) Murcia: editorial KR.

GÓMEZ-HERAS, M., SMITH, BJ., FORT, R. (2006). "Surface temperature differences between minerals in crystalline rocks: implications for granular disaggregation of granites through thermal fatigue", Geomorphology, 78 (3-4): 236-249.

GÓMEZ-HERAS, M., SMITH, B.J., FORT, R. (2008). "Influence of surface heterogeneities of building granite on its thermal response and its potential for the generation of thermoclasty", Environmental Geology, 56: 547-560.

GÓMEZ-HERAS, M., MCCABE, S., SMITH, B.J., FORT, R. (2009). "Impacts of Fire on Stone-Built Heritage: An Overview", International Journal of Architectural Heritage, 2 (15): 47-59.

GÓMEZ GONZÁLEZ, M., GÓMEZ ESPINOSA, T. (2001). “Diagnóstico y metodología de restauración en la escultura policromada", Arbor 169: 613-644.

GÓMEZ GONZÁLEZ, M. (2008). "Seguimiento científico de la restauración" La ciencia y el arte: ciencias experimentales y conservación del Patrimonio Histórico, 1: 259-269.

KRONLUND, D., LINDÉN, M., SMÅTT, J.H. (2016). "A polydimethylsiloxane coating to minimize weathering effects on granite", Construction and Building Materials, 124: 10511058. 
LARSON, S. (2003). "Shifting modern identities in Madrid's recent urban planning, architecture and narrative", Cities, 20(6): 395-402.

LIU, Q., HUANG, S., KANG, Y., LIU, X. (2015). “A prediction model for uniaxial compressive strength of deteriorated rocks due to freeze-thaw", Cold Regions Science and Technology, 120: 96107.

LÓPEZ-ARCE, P., VARAS-MURIEL, M.J., FERNÁNDEZ-REVUELTA, B., ÁlVAREZ De BUERGO, M., FORT, R., PÉREZ-SOBA, C. (2010). "Artificial weathering of Spanish granites subjected to salt crystallization tests: Surface roughness quantification", Catena, 83: 170-185.

PÉREZ-MONSERRAT, E.M., ALVAREZ DE BUERGO, M., GÓMEZHERAS, M., VARAS MURIEL, M.J., FORT, R. (2013). "An urban geomonumental route focusing on the petrological y decay features of traditional building stones used in Madrid, Spain", Environmental Earth Sciences, 69: 1071-1084.

POZO-ANTONIO, J.S., RIVAS T., FIORUCCI, M.P., LÓPEZ, A.J., RAMIL, A. (2016). "Effectiveness and harmfulness evaluation of graffiti cleaning by mechanical, chemical and laser procedures on granite", Microchemical Journal, 125: 1-9.

RIVAS, T., POZO, S., FIORUCCI, M.P., LÓPEZ, A.J., RAMIL, A. (2012). "Nd: YVO4 laser removal of graffiti from granite. Influence of paint and rock properties on cleaning efficacy", Applied Surface Science, 263: 563-572.

RODRÍGUEZ, A. (Coordinador) (2009). El patrimonio mundial en España: Una visión crítica, Madrid Secretaría general técnica. Subdirección General de Publicaciones, información y documentación.

SAJID, M., COGGAN, J., ARIF, M., ANDERSEN, J., ROLLINSON, G. (2016). "Petrographic features as an effective indicator for the variation in strength of granites". Engineering Geology, 202, 4454. doi:10.1016/j.enggeo.2016.01.001

SANJURJO SÁNCHEZ, J., VIDAL ROMANÍ, J.R, ALVES C. (2011). "Deposition of particles on gypsum-rich coatings of historic buildings in urban and rural environments", Construction and Building Materials, 25: 813-822.

SIEGESMUND, S., KERN, H., VOLLBRECHT, A. (1991). “The effect of oriented microcracks on seismic velocities in an ultramylonite", Tectonophysics, 186 (3-4): 241-251.

SIEGESMUND, S., VOLLBRECHT, A., PROS, Z. (1993). “Fabric changes and their influence on $\mathrm{P}$-wave velocity patterns-examples from a polyphase deformed orthogneiss", Tectonophysics, 225 (4-30): 477-492.

SILVA, B., AIRA, N., MARTÍNEZ-CORTIZAS, A., PRIETO, B. (2009). "Chemical composition and origin of black patinas on granite", Science of the Total Environment, 408 (1): 130-137.
SOUSA, L.M.O., SUÁREZ DEL RÍO, L.M., CALLEJA, L., RUIZ DE ARGANDOÑA, V.G., RODRÍGUEZ REY, A. (2005). "Influence of microfractures and porosity on the physico-mechanical properties and weathering of ornamental granites", Engineering Geology, 77: 153-168.

SOUSA, L.M.O. (2014). "Petrophysical properties and durability of granites employed as building stone: a comprehensive evaluation", Bulletin of Engineering Geology and the Environment, 73: $569-588$.

SOUSA, L.M.O., OLIVEIRA, A. S., ALVES, I. M. C. (2016). "Influence of fracture system on the exploitation of building stones: the case of the Mondim de Basto granite (north Portugal)", Environ Earth Sciences, 75-39.

TOVAR MARTíN, V. (1974). "El arquitecto Marcos López y el convento de Trinitarias Descalzas de Madrid", Anales del Instituto de Estudios Madrileños, 10: 133-153.

TOVAR MARTíN, V. (1990). "El monasterio de las religiosas Trinitarias Descalzas de San Ildefonso de Madrid", Anales del Instituto de Estudios Madrileños. Madrid.

VASCONCELOS, G., LOURENÇO, P.B., ALVES, C.A.S., PAMPLONA, J. (2008). "Ultrasonic evaluation of the physical and mechanical properties of granites", Ultrasonics, 48: 453-466.

VAZQUEZ, P., ACUÑA, M., BENAVENTE, D., GIBEAUX, S., NAVARRO, I., GOMEZ-HERAS, M., (2016). Evolution of surface properties of ornamental granitoids exposed to high temperatures, Construction and Building Materials, 104: 263-275. 


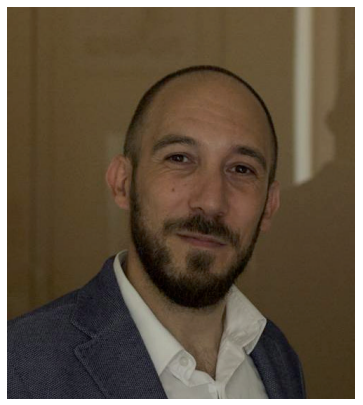

\section{David Martín Freire-Lista}

d.freire@igeo.ucm-csic.es

David Martín Freire-Lista holds a degree in Geological Sciences from the University of Oviedo (2001), a Master in Environmental Geology and Geological Resources from the Complutense University of Madrid (2010) and an European PhD in Geology and Geological Engineering (2016). His research focusses on petrophysics for heritage stone conservation, having worked at the Oviedo University (2000), Federal University of Minas Gerais (Brasil) (2000-2001), Federal University of Ouro Preto (Brasil) (2001-2002), Simón Bolivar University (Venezuela) (2002-2004), Bureau of Economic Geology (University of Texas, Austin) (2004-2005). He has been project manager in Central America from 2005 to 2007 and from 2008 he works at the "Applied Petrology for Heritage Conservation" of the Geosciences Institute (IGEO, CSIC-UCM).

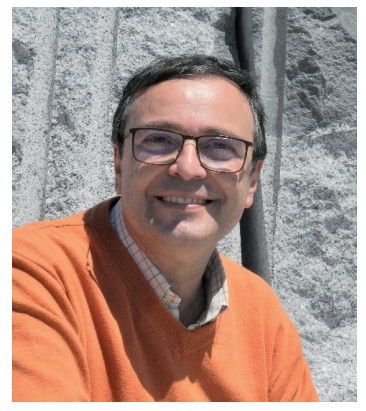

\section{Rafael Fort González}

rafael.fort@csic.es

Rafael Fort González. BSc. in Geological Sciences (1979) and PhD in Economic Geology (1985) from Complutense University of Madrid (UCM). Since 1987, Senior Scientist at (Spanish Council for Scientific Research, CSIC). Since 2006, - Head of the research group, from Geosciences Institute (IGEO, CSIC-UCM)., "Applied Petrology for Heritage Conservation" Research interests on: Buildings materials characterization (stone, bricks, mortars, etc.); quality and durability of stony materials. Conservation treatments, materials provenance: historic quarries. He has participated in 95 research contracts and agreements with private companies and public administrations. These past projects include research on decay processes and conservation methods on emblematic Spanish monuments. 